\section{The author replies}

O autor responde

Um sentimento de gratidão múltiplo! Aos edito res desse número do periódico Ciência \& Saúde Coletiva pela honrosa tarefa a mim delegada de desencadear um debate sobre a Reforma Psiqui átrica Brasileira em momento tão delicado e opor tuno. E a grata surpresa de ter provocado nos meus instigantes e generosos debatedores, uma transcendência de argumentos que extrapolam e muito os limites do singelo artigo disparador desse rico campo dialógico.

O diálogo com Itzak Levav é francamente fa cilitado pelo respeito que dedico àquele que foi o melhor articulador de políticas públicas de Saúde
Mental na região das Américas quando esteve na Organização Panamericana de Saúde. A aguda sensibilidade de Levav identifica algo que é cruci al: A Reforma Psiquiátrica Brasileira é exitosa, porém inconclusa. Ela é contra hegemônica por natureza. Esteve e estará dependente da dinastia de coordenadores nacionais da política de saúde mental, implicados com a Reforma, e seus recur sos pessoais de negociação na condução das polí ticas públicas do setor no país. Antes que se insta lem as redes de serviços comunitários nos territó rios, inimigos insidiosos impedem que a Refor ma se implante bancada de parlamentares de fensores das comunidades terapêuticas e dos hos pitais psiquiátricos, as academias conservadoras que não ousam produzir ciência e conhecimento do cuidar em liberdade, e ainda, o estigma arrai gado na sociedade civil e nas suas representações, nos governos, nas corporações profissionais, que jamais consentiram que se investisse nos disposi tivos da Reforma de forma eficiente.

Além de nos alertar que saúde mental não é apenas hospitais e serviços especializados, Levav traz para o Movimento da Reforma Psiquiátrica Brasileira o desafio de "culturalizar" iniciativas de promoção de saúde mental na vida em socie dade, advogando atenção para crianças e ado lescentes, populações indígenas, e outros grupos vulneráveis e excluídos de cuidados decentes.

Já Jair de Jesus Mari, dos mais produtivos e autorizados pesquisadores do país, põe em evi dencia que o Brasil é um país vitimizado cronica mente por desmandos técnicos, científicos e políti cos. Assiste se na chamada "indústria da loucu ra” a montagem de um parque hospitalar desi gual, particularmente concentrado nas regiões sudeste e nordeste, e vinculados a interesses políti cos privados, quando em todo o mundo já se repudiava os manicômios e se rumava "hacia la comunidad”, desde 1955. As evidências epidemioló gicas assinalam que os transtornos depressivos, ansiosos, somatoformes, os mais prevalentes nas populações, devem ser tratados com procedimen tos ambulatoriais, e que existe um melhor prog nóstico nos transtornos graves e severos de hu mor e esquizofreniformes quando tratados na comunidade em redes sociossanitárias. Por que então a fixação de setores importantes das Uni versidades e das corporações de profissionais em defender e instalar se em hospitais psiquiátricos nas suas práticas para os pobres, quando nos seus consultórios privados tratam todos os trans tornos dos que lhes podem pagar? Seriam ricos e pobres seres humanos de espécies diferentes, re querendo cenários opostos para serem tratados? 
Já Ana Marta Lobosque no seu texto tocante consegue integrar e valorizar a experiência psico patológica e subjetiva dos sujeitos que sofrem com transtornos mentais e a clareza política dos que advogam com rigor, e há muito, um modo de cuidado que inclua a experiência da loucura no território, no mundo em que todos vivem. Para cuidar em liberdade, é preciso que essas re des sejam descentralizadas... devem estender se na tessitura do espaço social, tornando se cada vez menos técnicas e menos sanitarizadas.

Endossando o que ela nos traz vou defender, entretanto, uma competência técnica e sanitária sofisticada no sentido da escuta, no manejo do sintoma, da organização dos serviços e da arti culação da rede territorial de cuidados sanitários específicos... a favor da Reforma e não contra ela. Quiçá não seja uma divergência, mas quero assumir o ridículo de exigir que todos aqueles profissionais de saúde que defendem a Reforma Psiquiátrica sejam também militantes de uma clínica ampliada do sujeito vivendo em liberdade nos diferentes serviços substitutivos ao manicô mio. Advogo também que sejam sujeitos impli cados nos movimentos sociais organizados, para que possam com conhecimento de causa criticar os erros eventuais desses movimentos. E ainda, a partir de suas boas provocações, denunciar o "gozo antimanicomial" dos que reclamam das situações aviltantes dos manicômios, mas con vivem pacificamente com eles e nada constroem como alternativa. Respeitaríamos mais esses crí ticos se estivessem também desconstruindo ma nicômios, inovando nos serviços territoriais para fazê los mais potentes e resolutivos, como ocor reu com os militantes nos processos de Reforma de países como Itália, Canadá e Holanda.

Vivemos um momento crítico quando a "pro blemática das drogas" justifica uma ameaça de retorno ao "enclausuramento" como política pú blica para a guarda dos usuários de substâncias psicoativas, esquecendo prejuízos oriundos des sa escolha no passado. Desconsideram assim a Lei Federal 10216/2001 que prescreve que a "li berdade é terapêutica" e ordena governos, socie dade e povo, a criar redes e estruturas de cuida dos que tornem a lei factível.

O que está publicado no Relatório da IV Con ferência Nacional de Saúde Mental Intersetorial, 2010 e nas Conferências anteriores (www.saude. gov.br) bem documentam os anseios de cada época. Também o movimento social implicado (ABRASME, MNLAM, RENILA, MDRP) publi cam suas insatisfações e querem ser considera dos nas decisões. Associam se também comuni dades acadêmicas, conselhos e associações pro fissionais, organizações internacionais como a World Health Organization (WHO), Pan Ame rican Health Organization (PAHO), World As sociation for Psychosocial Rehabilitation (WAPR) e inúmeras Associações de Usuários e Familiares espalhadas pelo país na defesa de re des resolutivas e comunitárias de cuidados.

Desconsiderar esse desejo de "cuidar em li berdade" significaria uma grave afronta aos Di reitos Humanos duramente conquistados. Um retorno ao "Estado de fato" quando governantes decidiam o que fazer com o Brasil sem levar em conta a Lei e os acordos democraticamente esta belecidos.

Nesse sentido, a valiosa contribuição de Sueli Dalari, ativista pioneira do Direito Sanitário no país, vem a nosso favor quando defende que ape nas uma política pública sanitária que tenha sido elaborada com a participação popular e forma lizada em diferentes suportes legais, nos Municí pios, nos Estados e na União, poderá ser reco nhecida como um direito vigente no Brasil.

Por que quando o SUS se implica responsa velmente com os usuários de crack lembrando o princípio constitucional "a saúde como um di reito de todos e um dever do estado" tem que investir dinheiro e assumir como tecnicamente o mais adequado o que se faz nas "comunidades terapêuticas", herança da dessassistência pública aos usuários de substâncias psicoativas no Bra sil? Por que não se utiliza o dinheiro novo do SUS e SENAD para criar a rede de atenção médico psicossocial e intersetorial faltantes, envolvendo um mutirão dos diversos implicados, que pos sam "substituir progressivamente" os espaços de enclausuramento, conforme reza a Lei Federal $10.216 / 2001$, tão corajosa e democraticamente conquistada e nesse momento tão duramente violada nessa escolha manicomializante?

As políticas públicas devem, como visto, as segurar a participação popular na Administra ção para legitimar suas decisões normativas. É preciso que todo o arcabouço normativo, so bretudo o sanitário, seja construído com a efeti va participação de todos os interessados, retoma Dallari, iluminando nossas consciências para um "estado de Direito" que não devemos perder de perspectiva.

Fato novo e louvável é a questão do trata mento de usuários de substâncias psicoativas ter entrado na agenda da presidência da República. Entretanto, excluir e trancafiar longe do olhar público "os loucos de todo o gênero", os droga dos e os malfeitores é uma tentação antiga (Mi 
chel Foucault na sua "História da Loucura", Erwing Goffman em "Manicômios, Prisões e Conventos", Franco Basaglia com os seus "Cri mes da Paz" já denunciavam com esmero esses humanos vícios).

Por fim Benilton Bezerra nos brinda com a sua lucidez ao identificar que a sociedade mu dou, a psiquiatria não é mais a mesma, e os mi litantes da Reforma se espalham entre o interior do estado e os movimentos sociais para realçar o que o Movimento da Reforma Psiquiátrica Bra sileira acaba de evidenciar: é uma metamorfose ambulante e portanto não se exauriu! E encon trada nas redes sociais da internet, em audiências públicas, no congresso nacional, na presidência da República, formas vivas e não fagocitadas de defender a liberdade e a democracia como valo res inalienáveis no enfrentamento de quaisquer problemática social e de saúde que historicamente se coloque. E as drogas e o Crack demonizado são a bola da vez!

Resta nos aceitar e aproveitar o conflito que esse desafio atual nos traz e pontuar com Benil ton Bezerra duas grandes fontes de enfrentamen to: como formar profissionais competentes e crí ticos o bastante para levar adiante o ideário de mocrático e o impulso instituinte, transforma dor, que caracterizou a história da Reforma?; abandonar o discurso defensivo em relação ao tema da avaliação e ir a campo e avaliar os CAPS, os hospitais, as urgências e as emergências, e toda a rede de cuidados, encontrando seus pontos fra cos, na perspectiva da melhoria da qualidade do cuidado; e, finalmente, mas não menos impor tante acrescento o desafio ético de seguir na Stul tifera Navis capitaneando a Reforma Psiquiátri ca Brasileira, em mares de tensão e conflito pró prios do campo da Reforma, amealhando as pe quenas conquistas cotidianas de escutar o sofri mento do Outro com inclusão social, dignidade e liberdade de Ser, num país com equidade e cida dania para todos.

\section{Agradecimentos}

Alfredo Schechtmann e Maria da Graça Ribeiro. 